\title{
THE NEED OF ENGLISH AT HIGHER EDUCATION
}

\author{
Yulia Hapsari \\ English Language Education, Universitas Brawijaya, Indonesia \\ Email: yulia_hap@yahoo.com \\ Esti Junining \\ English Language Education, Universitas Brawijaya, Indonesia \\ Email: esti_junining@yahoo.com \\ Devinta Puspita Ratri \\ English Language Education, Universitas Brawijaya, Indonesia \\ Email: devinta@ub.ac.id
}

APA Citation: Hapsari, Y., Junining, E., \& Ratri, D. P. (2017). The need of English at higher education. Indonesian EFL Journal, 3(1), 31-38

\begin{abstract}
Issues related to the need of English at higher education continue to be a discussion among scholars. Many believe that there is a positive relationship between English language skills of university students and their academic performance, and that English language skills are highly valued as a graduate attribute for employability. However, there are still few actions taken to gain information regarding which specific English language skills needed by educators and academic support staff. Universitas Brawijaya (UB) as one of the prominent higher education institutions in Indonesia is continuously taking actions to keep improving the quality of its graduates. One of the actions is to help its students to have a decent level of English language skills in order to help them to be ready to compete in work market that is going global. To reveal English language skills needed by bachelor graduates of the university as well as the reasons behind the need, sets of questionnaire were distributed to the educators in this case represented by the deans and academic support staff and the heads of academic support units both in the faculty and university level. The data from the questionnaires were then analyzed qualitatively. The findings of this study demonstrated that the educators need Reading and Writing skills more than the other two skills. This finding supports the idea that reading and writing skills are desperately needed to increase the number of publication in UB. Different from this result, the academic support staff perception on the need of English for the employees is on speaking skills. They think that speaking skills are the most needed skills for the employees to be able to handle the guest, and as a speaker of the units.

Keyword: need of English, English language skills, higher education
\end{abstract}

\section{INTRODUCTION}

The status of English today sets it apart from other foreign languages. In developing countries, English is often tied to development goals, expansion of the service sector, and increased connectivity to the rest of the world. In Indonesia, many efforts have been done to increase students' English proficiency level, nevertheless students of higher education.

Universitas Brawijaya (UB) as one of the prominent higher education institutions in Indonesia is also continuously taking actions to keep improving the quality of its graduates. A qualified university graduate is a must in order to make them ready to win competition in the world market that is going global. It is not only the graduates' personal and interpersonal quality that matter, but the inevitable requirement to be internationally recognized includes their decent English proficiency. English Proficiency Index (EPI) of English First (EF), an international English language institution, put Indonesia in 'moderate' category or having intermediate English proficiency level. However, in relation to English fluency, Indonesia remains positioned below its neighboring countries; 
Yulia Hapsari, Esti Junining, \& Devinta Puspita Ratri The Need of English at Higher Education

namely, Singapore, Malaysia, and even Vietnam.

Issues related to English proficiency in academic life especially in higher education have also been a discussion among scholars and professionals. A study conducted on the impact of IELTS scores on performance at an Australian university has reported a significant and positive relationship between language proficiency of international university students and their overall academic performance as measured by their GPA (Feast, 2002). In 2012, Wilson and Komba pointed out that there is a significant weak positive relationship between English Language Proficiency and students' academic achievement. It means that the English Language Proficiency is positively connected with academic success. Similar findings were also revealed by Ghenghesh (2015) who indicated that there is a significant but moderate positive relation between the students' proficiency in English and their overall academic success. Specifically, the higher the English proficiency of students on entry to the university, the better they performed in their degree area courses as well as in their English levels. Aina et al. (2013) also came with evidence that students of technical education who pass their English subject performed better than those who failed. The positive relationship between English proficiency and academic performance is also seen from a research by Martirosyan et al. (2015) stating that the highest mean GPA was evident among students who had reported high levels of selfperceived English language proficiency.

There are some strategies that higher education can do in making English language development becomes a central element of their learning and teaching. Strategies include institutional strategic plans; monitoring and evaluating English language entry requirements; diagnostic testing; and integrating communication skills as learning outcomes within disciplinary teaching (Arkoudis, et.al, 2014). Centre for the Study of Higher Education, The University of Melbourne, Australia set English Language Proficiency (ELP) and Employability Framework in 2014. This framework has been designed to inform and support higher education institutions' (HEIs) policies and practices on ELP and graduate employability. Linking ELP and employability together in the Framework was supported by the general agreement in the literature that communication skills are highly valued as a graduate attribute for employability. Nevertheless, there is limited study - if anythat shows any evidence of any relation between English Language proficiency and work performance.

Accordingly, it is evident that English plays an important part in the life of university education in that English is offered as a subject that is obligatory to be taken by the students. It is believed that a good proficiency of English will help the students to progress with their education. On the contrary, students who have low competency of English might suffer from difficulties when they have to engage in classroom activities involving English as the medium of instruction. It is so as nowadays numorous references used are written or available in English. Without a good mastery of reading skills, undestanding the references will be challenging. Besides, publication of journal, in which the abstract is necessary to be written in English, upon completing the study is one of the requirements the students have to fulfill. That indicates that writing skills in English is another skill to master. In addition, many classes in many faculties now are designed or opened as international classes in which English serves as the medium of instruction. Consequently, students wanting to be enrolled in such a class must be fluent in English orally and in written form.

Hence, it is apparent that English proficiency plays an important role in the academic world. English proficiency is the students' aptitude in using English in communicating both orally and in written form during their study at the university (DEEWR) as cited in (Ghenghes, 2015). It indicates that students are forced to have good skills of listening, speaking, reading, as well as writing.

Universities, as one of educational institutions, have always tried to find ways in ensuring the quality of their inputs and 
outputs. In doing so, one of the ways taken is by setting some requirements to fulfill by the applicants as well as by the graduate-to-be. Requiring the inputs or output to pass a certain passing grade of an English standardized test is one of the ways.

\section{Curiosity of what English proficiency} should be mastered by university graduates underlies this study. UB is chosen as the place to conduct the study because it is one of the prominent universities in Indonesia that has very large numbers of students coming from all over Indonesia and even some countries in Asia. In order to get a vivid picture of the need of English proficiency for bachelor graduates, educators and academic support staff from faculties in UB were involved to respond to a set of questionnaire revealing their expectation of what English proficiency should be mastered by bachelor graduates and the reasons underlying their answers.

This study is considered important to be conducted as the result should be beneficial for the English teaching in the university so that its graduate's quality, especially in English, is improved. Based on the elaboration of the background, this current study aims to describe the educators' perception on the need of English for bachelor graduates at UB, and describe the academic support staff's perception on the need of English for bachelor graduates at UB.

\section{METHOD}

The study was conducted around three months from August to October 2016, at UB, a public university in Malang, Indonesia by involving deans and head of administrative staff from different faculties in the university. The choice of the aforementioned university was based on the consideration that it is one of the best universities in Indonesia and many of its faculties have international standard proven by international accreditation certification. Not only students, but lectureres and volunteers from other countries also come to UB for their study and their career. As all faculties in UB are improving their quality required to be a world class university, the need of English proficiency is a must, both for its students and employees - many of them are UB graduates.

Since this study intends to describe the need of English expected to be mastered by bachelor graduated from UB seen from the educators and academic support perspectives, qualitative research was conducted. Qualitative research is a study which seeks to understand a phenomenon by focusing on the total picture rather than breaking it down into variables (Ary et al., 2006).

Data were gained from distributing questionnaire to dean of all faculties to uncover the need of English from academic perspective and to head of administrative staff of all faculties in UB to reveal the need of English from academic support.

Subsequently, the data gained from the questionnaire were analyzed to map the English proficiency needed seen from educators and academic support perspective. The result of this analysis will be elaborated descriptively.

Prior to collecting data needed in this research, the instrument employed to collect the data on English proficiency needed by bachelor graduates was designed. The questionnaire was developed both in a closeended and open-ended question to inquire as much information as possible.

Due to limited and less reliable previous studies which discuss the same topic as this study, the instruments were developed through some steps. Prior to developing the questionnaire, blue print is composed as the principle in developing the items in the questionnaire. The blue print of the questionnaire comprises English proficiency needed. The English proficiency test refers to the four language skills; reading, listening, writing, and speaking with proficiency descriptions. Each description represents different proficiency level. This description is a result of wrapping up English proficiency level of each language skill in TOEFL, TOEIC, and IELTS test.

Two sets of questionnaire were developed based on the blue print. One set was given to the deans to get data needed from academic perspective, and the other set was given to head of academic support staff 
Yulia Hapsari, Esti Junining, \& Devinta Puspita Ratri The Need of English at Higher Education

such as the head of administrative unit both in the faculty and university level to get the data needed from academic support perspective.

There were two kinds of data obtained from the questionnaire. The first was in the form of percentage of the result of the questionnaire. Some of the items distributed to the respondents were presented using Likert scale in terms that the respondents were provided five options on the answer ranging from the lowest to the highest scale. In processing this type of data, the researchers processed it in simple statistical way to finally come to the percentage result. Having finished with the calculation, the researchers were able to see the respondents' opinion regarding the issue raised in the questionnaire.

The second data was descriptive. It is from this type of data that the researchers were able to get further additional information. The items presented with options in Likert scales were also accompanied with spaces where the respondents could state their reasons. The researchers then analyze their reasons descriptively. Besides, the questionnaire also contained some items that were presented in open-ended questions. The answers of which were descriptively analyzed. The procedures in doing the analysis were by listing, selecting or sorting out, and interpreting the data. Listing the data refers to the process where the researchers noted down all of the answers as what they were. The second process was sorting out the data. This process was aimed at avoiding data overlapping. There might be possibilities that different respondents have similar ideas. It was in this process that same opinions were grouped. The last stage was interpreting the data. This means that the researchers decode the information obtained from the respondents in regards to the issues raised.

\section{RESULTS AND DISCUSSION Educators' Perception on the Need of English}

The educators' perspectives which are represented by the deans of nine faculties in UB agree that undergraduate students should master the four language skills namely speaking, listening, writing, and reading adequately with the emphasis on reading skill. The detailed explanation is described in table 1 to 4 .

\section{The Need of Speaking Skills}

Speaking skill is the first skill asked in the questionnaire. The result of speaking skill analysis is shown in the following table.

Table 1. Educator's Perception on the Need of Speaking Skills

\begin{tabular}{|c|c|c|c|c|c|}
\hline Speaking & 1 & 2 & 3 & 4 & 5 \\
\hline a. Graduates are able to deliver message orally & $44 \%$ & $22 \%$ & $11 \%$ & $11 \%$ & $11 \%$ \\
\hline b. Graduates are able to use good grammar in oral communication. & $33 \%$ & $33 \%$ & $11 \%$ & $11 \%$ & $11 \%$ \\
\hline c. Graduates are able to use English orally in all of different occasion. & $33 \%$ & $44 \%$ & $1 \%$ & $11 \%$ & $11 \%$ \\
\hline
\end{tabular}

From the table, it can be seen that $44 \%$ of the educators who are represented by the deans expect that UB students are able to communicate by using English in all of different occasions. They prefer students who have good speaking ability and have confidence to deliver message in English.

There is a reason that underlies the respondents to consider speaking skills as one of the language skills that the graduates have to master. It is simply because this skill is ultimately needed for communication, especially in international context and setting. Speaking ability will help the graduates to be able to compete internationally. In point of fact, this idea is in line with the goal set by the university that is to be a world class university.

However, some of the repondents believe that the skill of speaking in English is not the most important among others. Their view is based on the conviction that oral mastery of English is not the only requirement for communication to take place. As long as the message is delivered in communication, speaking skills can be put aside. Furthermore, not all graduates will have to interact with English-speaking people in their 
future jobs. Only $40 \%$ of the total graduates continue their study abroad or work in multinational companies. While the rest $60 \%$ of the total have their carreer in Indonesia and even use local language for communication.

\section{The Need of Listening Skills}

As one of the receptive skills, listening should be mastered by undergraduate students. The need of listening can be seen in Table 2.

Table 2. Educators' Perception on the Need of Listening Skills

\begin{tabular}{|c|c|c|c|c|c|c|}
\hline \multicolumn{2}{|r|}{ Listening } & 1 & 2 & 3 & 4 & 5 \\
\hline a. & $\begin{array}{l}\text { Graduates are able to recognize the main idea of short spoken text } \\
\text { presented in audio recording and direct spoken English. }\end{array}$ & $45 \%$ & $33 \%$ & $11 \%$ & $11 \%$ & - \\
\hline b. & $\begin{array}{l}\text { Graduates are able to classify specific information in dialog or short } \\
\text { spoken text. }\end{array}$ & $56 \%$ & $22 \%$ & - & $22 \%$ & - \\
\hline c. & $\begin{array}{l}\text { Graduates are able to identify the implied and stated meaning of } \\
\text { conversation. }\end{array}$ & $56 \%$ & $22 \%$ & $11 \%$ & $11 \%$ & - \\
\hline d. & Graduates are able to discover ideas with minimum repetition. & $33 \%$ & $45 \%$ & - & $11 \%$ & $11 \%$ \\
\hline & $\begin{array}{l}\text { Graduates are able to pinpoint ideas correctly and use grammar } \\
\text { appropriately. }\end{array}$ & $33 \%$ & $45 \%$ & - & $11 \%$ & $11 \%$ \\
\hline
\end{tabular}

Table 2 describes the need of listening to understand oral communication. Most of the deans share ideas that undergraduate students should be able to recognize main ideas, classify specific information, identify both implied and stated information, discover ideas with minimum repetition, and pinpoint ideas correctly using appropriate grammar.

Listening skill is required to help the graduates to be able to grab the ideas of spoken English. In turn, the graduates will be able to communicate with foreigners without obstacles.

\section{The Need of Reading Skills}

Reading skills take place as the most frequent skills needed by the undergraduate. It is figured out in Table 3.

Table 3. Educators' Perception on the Need of Reading Skills

\begin{tabular}{|c|c|c|c|c|c|c|}
\hline & Reading & 1 & 2 & 3 & 4 & 5 \\
\hline a. & $\begin{array}{l}\text { Graduates are able to identify stated main idea of the text in } \\
\text { English. }\end{array}$ & $67 \%$ & $11 \%$ & - & - & $22 \%$ \\
\hline b. & $\begin{array}{l}\text { Graduates are able to distinguish implied main idea of the text in } \\
\text { English. }\end{array}$ & $67 \%$ & $11 \%$ & - & - & $22 \%$ \\
\hline c. & Graduates are able to pinpoint vocabulary in various English texts. & $34 \%$ & $33 \%$ & $11 \%$ & $22 \%$ & - \\
\hline d. & Graduates are able to recognize grammar in various English texts. & $33 \%$ & $45 \%$ & $11 \%$ & $11 \%$ & - \\
\hline
\end{tabular}

From Table 3, it can be stated that most of the deans need undergraduate students who are able to have high skills in reading especially in distinguishing between stated and implied main ideas of the text (67\%). This table shows the highest need of reading skills among the other skills.

There are several reasons that are used as the basis why the respondents consider reading skill as the most needed aspect of language to be mastered by the graduates. One of the reasons is because good skill of reading helps the graduates understand the content of the materials when they were still studying at the university. It is so as many journals used for classes are presented in English. The updated world-wide information can also be accessed by reading. Besides, reading skill will help the graduates to avoid misinterpreting the information made available for them.

\section{The Need of Writing Skills}

Similar to reading skill, writing skill also takes place as the most required skills in higher education. The explanation is shown in Table 4. 
Yulia Hapsari, Esti Junining, \& Devinta Puspita Ratri

The Need of English at Higher Education

Table 4. Educators' Perception on the Need of Writing Skills

\begin{tabular}{|c|c|c|c|c|c|c|}
\hline & Writing & 1 & 2 & 3 & 4 & 5 \\
\hline a. & Graduates are able to write reports in English. & - & $56 \%$ & $33 \%$ & $11 \%$ & - \\
\hline b. & Graduates are able to design a slide show presentation in English. & $22 \%$ & $56 \%$ & - & $11 \%$ & $11 \%$ \\
\hline c. & Graduates are able to write various documents in English. & - & $56 \%$ & $33 \%$ & $11 \%$ & - \\
\hline d. & $\begin{array}{l}\text { Graduates are able to produce a written form using a good English } \\
\text { grammar. }\end{array}$ & - & $66 \%$ & $12 \%$ & $11 \%$ & $11 \%$ \\
\hline
\end{tabular}

Table 4 indicates the need of writing skill involving the ability to write in a good English grammar (66\%) followed by writing a report, designing a slide show for presentation, and writing various documents needed in working places respectively.

All respondents believe that writing skill needs to be improved. It is so as writing skills of undergraduate students are still low. Writing is needed to deliver and get ideas acrossed. However, it is quite obvious that writing is bothersome, moreover to students of non-English department. Upon realizing this, the respondents think that the teaching of writing is needed to help the students to be able to write an abstract for their final report.

\section{Academic Support Staff Perception on the Need of English}

The respondents of the academic support staff involves the personnel in charge of the five different academic support units such as 1) the head of administrative staff in the Faculty of Cultural Studies, 2) the head of student affairs in the Faculty of Engineering, 3 ) the head of financial affairs in the Faculty of Administrative Sciences, 4) the head of Personnel Bureau in UB, and 5) the head of Information and Technology Unit in UB.

1. The Need of Speaking Skills for Employees Table 5 describes the need of speaking skills among the employees.

Table 5. The Academic Support Staff Perception on the Need of Speaking Skills

\begin{tabular}{|c|c|c|c|c|c|}
\hline & Speaking & 1 & 2 & & 5 \\
\hline a. & Graduates are able to deliver message orally. & $60 \%$ & $20 \%$ & $20 \%$ & - \\
\hline b. & Graduates are able to use good grammar in oral communication. & - & $\mathbf{8 0 \%}$ & $20 \%$ & - \\
\hline c. & Graduates are able to use English orally in all of different occasion. & $60 \%$ & $20 \%$ & - & $20 \%$ \\
\hline
\end{tabular}

From Table 5, it is clearly seen that most of the academic support staff prefer to have employees who are able to speak in a good English grammar. Besides, the employees should have other speaking skills such as delivering message orally in a different occasion.

2. The Need of Listening Skills for Employees The need of listening skills for employees is described in Table 6.

Table 6. The Academic Support Staff Perception on the Need of Speaking Skills

\begin{tabular}{|c|c|c|c|c|c|c|}
\hline & Listening & 1 & 2 & 3 & 4 & 5 \\
\hline a. & $\begin{array}{l}\text { Graduates are able to recognize the main idea of short spoken } \\
\text { text presented in audio recording and direct spoken English. }\end{array}$ & $40 \%$ & $20 \%$ & $40 \%$ & - & - \\
\hline b. & $\begin{array}{l}\text { Graduates are able to classify specific information in dialog or } \\
\text { short spoken text. }\end{array}$ & $20 \%$ & $60 \%$ & $20 \%$ & - & - \\
\hline c. & $\begin{array}{l}\text { Graduates are able to identify the implied and stated meaning of } \\
\text { conversation. }\end{array}$ & $60 \%$ & $20 \%$ & - & $20 \%$ & - \\
\hline d. & Graduates are able to discover ideas with minimum repetition. & $20 \%$ & $60 \%$ & - & $20 \%$ & - \\
\hline e. & $\begin{array}{l}\text { Graduates are able to pinpoint ideas correctly and use grammar } \\
\text { appropriately. }\end{array}$ & $20 \%$ & $60 \%$ & - & $20 \%$ & - \\
\hline
\end{tabular}


Table 6 describes the need of listening skill for employees under the respondents' responsibility. Among the five statements, classifying specific information, identifying implied and stated meaning, discovering ideas, and pinpointing ideas are considered as the important skills needed to be mastered by employees working in a particular unit.

3. The Need of Reading Skills for Employees The need of reading skills for employees is illustrated in table 7.

Table 7. Academic Support Staff Perception on the Need of Reading Skills

\begin{tabular}{|c|c|c|c|c|c|c|}
\hline & Reading & 1 & 2 & 3 & 4 & 5 \\
\hline a. & Graduates are able to identify stated main idea of the text in English.. & $40 \%$ & $40 \%$ & - & - & $20 \%$ \\
\hline b. & $\begin{array}{l}\text { Graduates are able to distinguish implied main idea of the text in } \\
\text { English. }\end{array}$ & $40 \%$ & $40 \%$ & $20 \%$ & - & - \\
\hline c. & Graduates are able to pinpoint vocabulary in various English texts. & $20 \%$ & $40 \%$ & $20 \%$ & $20 \%$ & - \\
\hline d. & Graduates are able to recognize grammar in various English texts.. & $60 \%$ & - & $20 \%$ & - & $20 \%$ \\
\hline
\end{tabular}

Among the four reading skills, recognizing grammar in various English texts is the most needed skill of reading for the employees. The respondents think that this skill effectively helps to understand an English text.
4. The Need of Writing Skills for Employees The explanation of the need of writing skills for employees is stated in table 8 .

Table 8. Academic Support Perception on the Need of Writing Skills

\begin{tabular}{|c|c|c|c|c|c|c|}
\hline & Writing & 1 & 2 & 3 & 4 & 5 \\
\hline a. & Graduates are able to write reports in English. & $40 \%$ & $40 \%$ & $20 \%$ & - & - \\
\hline b. & Graduates are able to design a slide show presentation in English. & $40 \%$ & $40 \%$ & - & - & $20 \%$ \\
\hline c. & Graduates are able to write various documents in English. & $40 \%$ & $40 \%$ & $20 \%$ & - & - \\
\hline d. & $\begin{array}{l}\text { Graduates are able to produce a written form using a good English } \\
\text { grammar. }\end{array}$ & $40 \%$ & $40 \%$ & - & $20 \%$ & - \\
\hline
\end{tabular}

Table 8 describes that ability to write reports in English, design slide show presentation in English, write various documents in English, and produce a written form using good English grammar takes equal importance among the employees. The respondents believed that a good writing skill is an indication of succesful working performance.

\section{Comparison on the Need of English between Educators and Academic Staff}

The explanation of the comparison on the need of writing skills for employees is stated in table 9 .

Table 9. Comparison on the Need of English between the Educators and the Academic Staff

\begin{tabular}{|c|c|c|c|c|c|}
\hline & Writing & $\begin{array}{c}\text { Speaking } \\
\%\end{array}$ & $\begin{array}{c}\text { Listening } \\
\% \\
\end{array}$ & $\begin{array}{c}\text { Writing } \\
\% \\
\end{array}$ & $\begin{array}{c}\text { Reading } \\
\%\end{array}$ \\
\hline & Educators' need of the four language skills & 10 & 20 & 30 & 40 \\
\hline b. & Academic staff need of the four language skills & 70 & 10 & 10 & 10 \\
\hline
\end{tabular}

Table 9 shows the comparison on the need of the four language skills between the educators and the academic staff. From the table, it can be concluded that the educators emphasize reading and writing skills more than listening and speaking skills. They expect that undergraduate students could master reading and writing skills more than listening and speaking skills. Different from educators' perspective, the academic supports staff prefer to have employees who are fluent in speaking more than listening, reading and writing.

To summarize, undergraduate students should master reading equally to writing in order to finish the bachelor degree, and employees need to have high communication skills more than the other skills in order to be a good employees who are able to handle the guests and other relation activities.

Briefly, it can be inferred that in order to be able to finish the study successfully, 
Yulia Hapsari, Esti Junining, \& Devinta Puspita Ratri The Need of English at Higher Education

undergraduate students should have skills in reading and writing more than the ability to listen and to speak. This statement is in line with Richards (1990) who states that English for Academic Purposes in higher education should emphasize on reading more than the other skills to increase students' schemata for a new knowledge. This finding seems to be relevant to the nature of English for Specific Purposes (ESP) that reading skills should be exposed more than the other language skills.

Regarding the second finding related to the need of English for communication skills among academic support staff, the results are in line with some studies related to this field. As Nunan (2002) states that communication is crucially needed in an administrative field. Therefore, it is needed to prepare the graduates with English skills needed in their professional world. Different from the educator's perspectives, it is true that a skillful academic support staff should have a good communication skill which is important to deliver a message orally in front of either the customers or clients.

\section{CONCLUSION}

From the finding of the study, there are two conclusions that can be taken into consideration in terms of the roles and functions. Firstly, different roles maintain different needs of English. It means that the need of English for educators is different from the need of English for academic support staff. This may be caused by the fact that educators need more exposures in reading for new information and writing for publication than those of the administrative staff. Secondly, administrative staff requires more communication skills than those of academic staff. These communication skills are mainly needed for handling the guests and making relationship with other customers or clients.

\section{REFERENCES}

Ghenghes, P. (2015). The relationship between English language proficiency and academic performance of university students - should academic institutions really be concerned?. International Journal of Applied Linguistics, 4(2).

Wilson, J., \& Komba, S. C. (2012). The link between English language proficiency and academic performance: A pedagogical perspective in Tanzanian secondary schools. World Journal of English Language, 2(4). 